Available online on 15.09.2020 at http://jddtonline.info
Open Access to Pharmaceutical and Medical Research
unrestricted non-commercial use, provided the original work is properly cited

Open 1 Access

Research Article

\title{
Screening of Aerial Parts of Kigelia Pinnata for its Antioxidant, Wound Healing and Antimicrobial Activity
}

\author{
Prashant Kaushik*, Vishal Shrivastava, Parul Mehata, Janki Prasad Rai \\ Department of Pharmacology, School of Pharmacy, LNCT University, Bhopal, Madhya Pradesh 462026, India
}

\begin{abstract}
The antioxidant activity was performed by DPPH Scavenging activity method and Hydrogen peroxide scavenging activity method. Ascorbic acid was taken as standard in both methods. DPPH and Hydrogen peroxide scavenging activity methods of $100 \mu \mathrm{g} / \mathrm{ml}$ extracts shows better $\%$ inhibition as compared to control and $50 \mu \mathrm{g} / \mathrm{ml}$ extracts. In DPPH Scavenging activity \% inhibition of $100 \mu \mathrm{g} / \mathrm{ml} \mathrm{methanolic}$ extracts was $60.72 \%$ and in Hydrogen peroxide scavenging activity it was found to be $26 \%$. Wound healing activity was performed by Incision wound model and Excision wound model. In incision wound healing model, the tensile strength of the 4\% test group and the Neosporin ointment treated group were comparable to each other. Tensile strength of $2 \%$ extract ointment showed lesser $3.38 \mathrm{gm} / \mathrm{mm}^{2} \mathrm{but}$ significant increase in tensile strength compared to the control group $2.91 \mathrm{gm} / \mathrm{mm}^{2}$. The tensile strength of $4 \%$ test group was found to be 3.44 gm/mm². Thus both concentrations of the extract as well as the standard drug showed a significant increase in tensile strength on the $9^{\text {th }}$ day. In excision models the animals treated with the $4 \% \mathrm{w} / \mathrm{w}$ KPME ointment were shown to healed completely as compared to $2 \% \mathrm{w} / \mathrm{w}$ which was also at the complete healing stage as compared to control treated and the standard drug (Neosporin) treated group. The epithelization period of standard group and treated group was less in comparison with that of simple ointment base treated groups. The percentage of wound contraction was much more with the $4 \% \mathrm{w} / \mathrm{w}$ extract was similar to that of Neosporin treated group. $2 \% \mathrm{w} / \mathrm{w}$ treated group of animals showed significant wound contraction. In antimicrobial activity, both antibacterial and antifungal potentiality was evaluated. In mic of antibacterial methanolic extract of Kigelia pinnta inhibit strains of E.coli and strain of Shigella boyelii, Salmonella aureus and Baccilus subtitis were found to be completely resistant. In mic of antifugal activity, all the fungal strain were inhibited by methanolic extract of Kigelia pinnata. These findings may provide a lead for further investigation of the overall pharmacological aciotns of Kigelia pinnata methanolic extract in more appropriate model.
\end{abstract}

Keywords: Kigelia pinnata, DPPH, Anti-oxidant, DMSO, ANOVA

Article Info: Received 19 July 2020; Review Completed 17 August 2020; Accepted 24 August 2020; Available online 15 September 2020

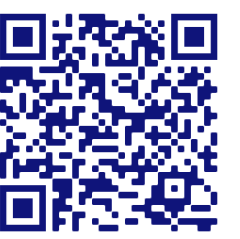

\section{Cite this article as:}

Kaushik P, Shrivastava V, Mehata P, Rai JP, Screening of Aerial Parts of Kigelia Pinnata for its Antioxidant, Wound Healing and Antimicrobial Activity, Journal of Drug Delivery and Therapeutics. 2020; 10(5):86-93

http://dx.doi.org/10.22270/jddt.v10i5.4360

Prashant Kaushik, Department of Pharmacology, School of Pharmacy, LNCT University, Bhopal, Madhya Pradesh, India

\section{INTRODUCTION}

Herbal medicine ("herbalism") is the study and use of medicinal properties of plants. Natural products are an integral part of human health care system because there is now popular concern over the toxicity and side effects of modern drugs ${ }^{1}$. In general use, herbs have been used for flavouring, foods, medicine or perfume. Herbs promote wellness since ancient times ${ }^{2}$. Keeping in view the increasing demand of herbal drugs over their synthetic counter parts and to counteract the global problem of multi and any drug resistance, the present study was designed to investigate and establish scientifically the folkfore uses of Kigelia pinnata as an antioxidant, wound healing and antimicrobial. Kigelia pinnata belonging to the family Bignoniaceae is cultivated in many parts of India as an ornamental and roadside tree ${ }^{3}$. It is also known as Balamkheera in Hindi and distributed all over
India but found abundantly in west Bengal. The plan of work comprises of collection and authentication of plant material followed by shade drying, grinding, extraction in soxhlet apparatus, phytochemical investigation and finally screening of various pharmacological activities as stated.

Antioxidants are widely used in dietary supplements and have been investigated for the prevention of diseases such as cancer, coronary heart disease and even altitude sickness ${ }^{4}$. Although initial studies suggest that antioxidant supplements might promote health, later large clinical trials with a limited number of antioxidants detected no benefit and even that excess supplementation with certain antioxidants may be harmful 5 .

Wound healing involves a complex series of interactions between different cell types, cytokine mediators, and the extracellular matrix ${ }^{6}$. The phases of normal wound healing CODEN (USA): JDDTAO 
include haemostasis, inflammation, proliferation, and remodeling. Each phase of wound healing is distinct, although the wound healing process is continuous, with each phase overlapping the next.

Wound-healing is a process that comprises three phases, e.g., inflammation, proliferation and remodeling, and proceeds with complicated and well-organized interaction between various tissues and cells by overlapping between successive stages 7,9 . Alterations in any of these steps can lead to delay or inability in dermal wound-healing. Therefore, woundhealing is not a linear process. It is rather a to and fro process that depends on various factors. There are many points at which the normal wound-healing process can be disturbed.

Microorganisms are the causes of many infectious diseases. The organisms involved include pathogenic bacteria, causing diseases such as plague, tuberculosis and anthrax; protozoa, causing diseases such as malaria, sleeping sickness and toxoplasmosis; and also fungi causing diseases such as ringworm, candidiasis or histoplasmosis ${ }^{8-11}$. However other diseases such as influenza, yellow fever or AIDS are caused by pathogenic viruses, which are not usually classified as living organisms and are not, therefore microorganisms by the strict definition.

\section{MATERIAL AND METHOD}

\section{Selection of plant and Authentication}

The plant was collected from Greater Noida and a herbarium was prepared which was then identified and authenticated at Pusa campus, New Delhi. After authentication the aerial parts of Kigelia pinnata was collected in bulk for experimental purpose. The leaves, bark-stem of Kigelia pinnata were shade dried and powdered with a mechanical grinder and stored in an air tight container ${ }^{12}$. The dried powder (300gm) was extracted with various solvents according to their polarity by using soxhlet apparatus for $36-72$ hours $^{13}$. The solvent were distilled off to $1 / 3$ rd volume and then they were transferred on a previous tarred vessel over water bath maintaining a temperature of $30^{\circ} \mathrm{C}-40^{\circ} \mathrm{C}$ to obtain a semi solid mass. The semi-solid mass was kept in a desicator for drying. The crude extract found to be $23 \% \mathrm{w} / \mathrm{v}$.

\section{Experimental animals:}

Wistar albino rats weighing between 130-250 gm of either sex were used for wound healing activity ${ }^{14}$. They were obtained from Central Animal House of NIET, Greater Noida. The experimental animals were housed in standard polypropylene cages at $25 \pm 20 \mathrm{C}$ with $12 \mathrm{hrs}$ light and $12 \mathrm{hrs}$ dark cycles. All the animals were fed with standard rat feed and water ad libitum was provided. The litter in the cages was renewed thrice a week to ensure hygenicity and maximum comfort for animals ${ }^{15}$. Ethical clearance for handling the animals was obtained from Institutional Animals Ethics Committee prior to the beginning of the project work bearing the protocol number NIET/IAEC/2011/39, studies were performed in according to guidance of CPSEA registration number is 1121/ac/CPSEA/07.

\section{Preliminary Phytochemical Screening:}

The coarsely powdered leaf and bark stem material were extracted with various solvents (Petroleum ether, Chloroform, Ethyl acetate, Methanol and Water) for phytochemical investigation 16,17 . The aim of this step was to decide the best solvent among all of the above, in which further extraction by soxhlet apparatus could be carried out. The best solvent would be the one in which maximum number of phytoconstituents could be detected $18.10 \mathrm{~g}$ of powdered aerial material was soaked in $25 \mathrm{ml}$ of each of benzene, petroleum ether, chloroform, methanol and water for $24 \mathrm{hrs}$, filtered and subjected to various phytochemical test.

\section{Antioxidant activity: \\ DPPH radical scavenging activity:}

Measurement of the free radical scavenging activity of extract of Kigelia pinnata aerial parts was done by decreasing the absorbance of methnol solution of 2, 2diphenyl-1-picryl-hydrazyl (DPPH). A stock solution of DPPH was prepared by dissolving $33 \mathrm{mg}$ DPPH in $1 \mathrm{~L}$ methanol and $5 \mathrm{ml}$ of this stock solution was added to $1 \mathrm{ml}$ of KPME solution at different concentration (50 and $100 \mu \mathrm{g} / \mathrm{ml}$ ). After 30 minutes, the absorbance was measured at $517 \mathrm{~nm}$ and compared with the standard 19 .

\section{Hydrogen peroxide scavenging activity:}

A solution of hydrogen peroxide $(40 \mathrm{mM})$ was prepared in phosphate buffer $(\mathrm{pH}$ 7.4). Extracts $(50 \mu \mathrm{g} / \mathrm{ml}$ and $100 \mu \mathrm{g} / \mathrm{ml}$ ) in distilled water were added to a hydrogen peroxide solution $(0.6 \mathrm{ml}, 40 \mathrm{mM})$ and absorbance measured at $560 \mathrm{~nm}$ using spectrophotometer against a blank solution containing phosphate buffer without hydrogen peroxide ${ }^{20}$ The percentage of hydrogen peroxide scavenging of both extracts and standard compound were calculated.

\section{Wound healing activity:}

\section{Purpose and rationale:}

Excision and incision on predetermined area inflicts wound on rats. Administration of wound healing agents heals the wound. Wound contraction, epithelisation time and tensile strength will be determined by the following model ${ }^{21}$.

\section{Selection and maintenance of experimental animals:}

Wistar albino rats weighing between 130-250 gm of either sex were used for wound healing activity. They were obtained from Central Animal House of NIET, Greater Noida. The experimental animals were housed in standard polypropylene cages at $25 \pm 2^{\circ} \mathrm{C}$ with $12 \mathrm{hrs}$ light and $12 \mathrm{hrs}$ dark cycle ${ }^{22}$. All the animals were fed with standard rat feed and water ad libitum was provided. The litter in the cages was renewed thrice a week to ensure hygenicity and maximum comfort for animals.

\section{Incision Wound Healing Model:}

Animals in each group were anaesthetized and one para vertebral-long incision was made through the skin and cutaneous muscles at a distance of about $1.5 \mathrm{~cm}$ from the midline on each side of the depilated back of the rat. Full aseptic measures were not taken and no local or systemic antimicrobials were used throughout the experiment. All the groups were treated in the same manner as that of excision wound model. No ligature was used for stitching. After the incision was made, the parted skin was kept together and stitched with black silk at $0.5 \mathrm{~cm}$ intervals; surgical thread (No. 000) and a curved needle (No. 11) were used for stitching23. The continuous threads on both wound edges were tightened for good closure of the wound. The wound was left undressed. Sample extract along with simple ointment (control) and standard drug were topically administered once daily for 9 days; when wounds were cured thoroughly the sutures were removed on the 10th day and tensile strength was measured with a local made Tensiometer. 


\section{Excision wound model:}

Rats were anaesthetized by open mask method with anaesthetic ether. The rats were epilated on the back and a predetermined area of $500 \mathrm{~mm}$ full thickness skin was excised from the dorsal inters scapular region ${ }^{24}$. Rats wounds were left undressed in open environment to monitor wound contraction and epithelisation time. The reference standard drug $(0.2 \%$ Neosporin ointment), white petroleum jelly, Kigelia pinnata methanolic extract ointment $(2 \%$ and $4 \% \mathrm{w} / \mathrm{w}$ of aerial parts) were applied everyday till the wound was completely healed. The progressive changes in the wound area were monitored by tracing the wound margin on a graph paper ${ }^{25}$. The measurement of wound area on graph paper was expressed as Wound contraction was expressed as percentage reduction of original wound size.

\section{Antimicrobial Activity:}

The antimicrobial activity of the methanolic extract of Kigelia pinnta was determined by MIC of extract against bacterial and fungal strains.

\section{Anti-bacterial activity \\ Determination of Minimum Inhibitory Concentration by Serial Dilution Technique:}

The leaf extract (stock solution) was reconstituted with a minimum amount of dimethyl sulfoxide (DMSO). This solvent did not posses any antimicrobial activity of its own. Calculated volume of this stock solution were dispensed in a series of McCartney bottles previously containing calculated volume of sterile cooled molten nutrient agar media $\left(40-45^{\circ} \mathrm{C}\right)$ to prepare final volume of $30 \mathrm{ml}$ each with dilutions of $5,10,25,50,100,200,400$, 800 and $1000 \mu \mathrm{g} / \mathrm{ml}$. Then these molten media containing varying concentration of extract were poured aseptically in pre-sterilized petri dishes $(70 \mathrm{~mm})$ to give sterile nutrient agar plates with varying dilution of extract ${ }^{26}$. These plates were then kept in refrigerator at $4^{\circ} \mathrm{C}$ for 24 hours to ensure uniform diffusion of extract. Then these plates were dried at $37^{\circ} \mathrm{C}$ for bacteria for 2 hours before spot inoculations. One loopful (loop diameter: $3 \mathrm{~mm}$ ) of an overnight grown bacterial strains suspension $\left(10^{5} \mathrm{CFU} / \mathrm{ml}\right)$ were added in each quadrant as marked by checker board technique .The spotted plates were incubated at $37^{\circ} \mathrm{C}$ for 24 hours for bacteria in an incubator and MIC values were obtained.

The agar dilution technique for assessment of antibacterial activity

The minimum inhibitory concentration of the various extracts against the bacteria strains were determined by the agar dilution technique ads described below.

\section{Preparation of stock solution of the extract ${ }^{27}$}

Desired amount of each of the methanolic extracts of Kigelia pinnata was dissolved separately in DMSO to prepare the stock solution of $10 \mathrm{mg} / \mathrm{ml} \& 1 \mathrm{mg} / \mathrm{ml}$ suitable dilution were from this to get various dilution of $0,5,10,25,50,100,200,400$ $\mu \mathrm{g} / \mathrm{ml}$.

Preparation of nutrient agar plate contacting different concentration of the extract of the extract required for determination of (MIC) minimum inhibitory concentration of the extract with respect to different bacteria

Measured volume of stock solution of the extracts were individually added aseptically to molten nutrient agar (oxoid) in the following concentration $(\mu \mathrm{g} / \mathrm{ml}): 0$ control, 5 , $10,25,100,200,400,800 \& 1000 \mu \mathrm{g} / \mathrm{ml}$ poured in to sterile Petri dishes. The $\mathrm{pH}$ of the media was adjusted to 7.2-7.4 For uniform diffusion of the extract throughout the medium the agar plates contacting extract were refrigerated overnight and subsequently dried for 1 hour at $37^{\circ} \mathrm{C}$ in B.O.D incubator before use small squares were diameters at the back of agar contacting portion of the plates with a marker to specify the actual location for each test organism ${ }^{28}$.

\section{Inoculum}

The inoculums for determination of the sensitivity pattern consisted of one loopful of an overnight grown broth culture of the test organism. The average size of the inoculums was about $10^{5}$ cells contained in a $2 \mathrm{~mm}$ diameter loop.

\section{Spot Inoculation method}

When the nutrient agar petri dish contacting the extract and also the control petri dish having equal volumes of solvent were made ready, the overnight growth broth culture of each test organism was spot inoculated by checker -board technique on the marked area of the $100 \mathrm{~mm}$ petri dish ${ }^{29}$. These were then incubated for overnight at $37^{\circ} \mathrm{C}$. No growth of the organism on the test petri dish along with growth on the control dish was taken as an indication of antimicrobial activity of the extract. The readings were recorded in a tubular form. Minimum Inhibitory concentration (MIC) was indicated by the lowest concentration of the extract with inhibited the bacterial growth ${ }^{30}$.

\section{Determination of Zones of inhibition by Disc Diffusion Method}

The stock solution (each of $10 \mathrm{mg} / \mathrm{ml}$ ) of both extract and ciprofloxacin were prepared. From these stock solutions two sets of four dilutions $(200,400, \mu \mathrm{g} / \mathrm{ml})$ each of plant extract (solvent: DMSO) and ciprofloxacin (solvent: sterile distilled water) were prepared in sterilized McCartney bottles. However we have compare the activity of griseofulvin with the extract at 1000 and $1500 \mu \mathrm{g} / \mathrm{ml}$. Sterile agar plates were prepared and incubated at $37^{\circ} \mathrm{C}$ for bacteria for 24 hours to check for the presence of any sort of contamination. Then each sterilized agar plates were flooded with liquid culture of the strains, dried for 30 minute at $37^{\circ} \mathrm{C}$ for bacteria ${ }^{31}$. The sterile whatman filter paper disc $(4 \mathrm{~mm}$ diameter) were soaked in four different dilution of the crude extract and placed in appropriate position of the plates marked as quadrant at the back of Petri dishes. All the flooded plates with corresponding paper discs soaked with appropriates dilution of extract were incubated for 24 hours \& diameter of zone of inhibition were measured in $\mathrm{mm}$. Similar procedure was adopted for reference standard drug \& corresponding zone diameters were measured \& compared accordingly.

\section{RESULT AND DISCUSSION}

Phytochemical Investigation

The results of phytochemical investigation are as follow. 
Table 1: Preliminary phytochemical investigation of leaves stem-bark extract of Kigelia pinnata in different solvents:

\begin{tabular}{|c|c|c|c|c|c|}
\hline \multirow[b]{2}{*}{ Phytoconstituents } & \multicolumn{5}{|c|}{ Solvent } \\
\hline & Petroleum ether & Chloroform & Ethyl acetate & Methanol & Distilled water \\
\hline \multicolumn{6}{|l|}{ Alkaloids } \\
\hline Dragendorff's reagent & - & + & + & + & - \\
\hline Mayer's reagent & - & - & - & - & + \\
\hline Wagner's reagent & - & - & - & + & - \\
\hline Hager's reagent & - & + & + & + & + \\
\hline \multicolumn{6}{|l|}{ Carbohydrates } \\
\hline Molisch's test & + & - & - & - & - \\
\hline Pentose test & - & + & - & - & - \\
\hline Benedict's test & - & - & - & + & + \\
\hline \multicolumn{6}{|l|}{ Glycosides } \\
\hline Baljet's test & - & - & - & + & + \\
\hline Legal's test & - & - & - & - & + \\
\hline \multicolumn{6}{|l|}{ Steroids } \\
\hline $\begin{array}{l}\text { Libermann - } \\
\text { Burchard test }\end{array}$ & + & - & + & - & - \\
\hline Sulfur powder test & + & + & + & + & + \\
\hline Flavonoids & & & & & \\
\hline
\end{tabular}

Anti-0xidant Activity:

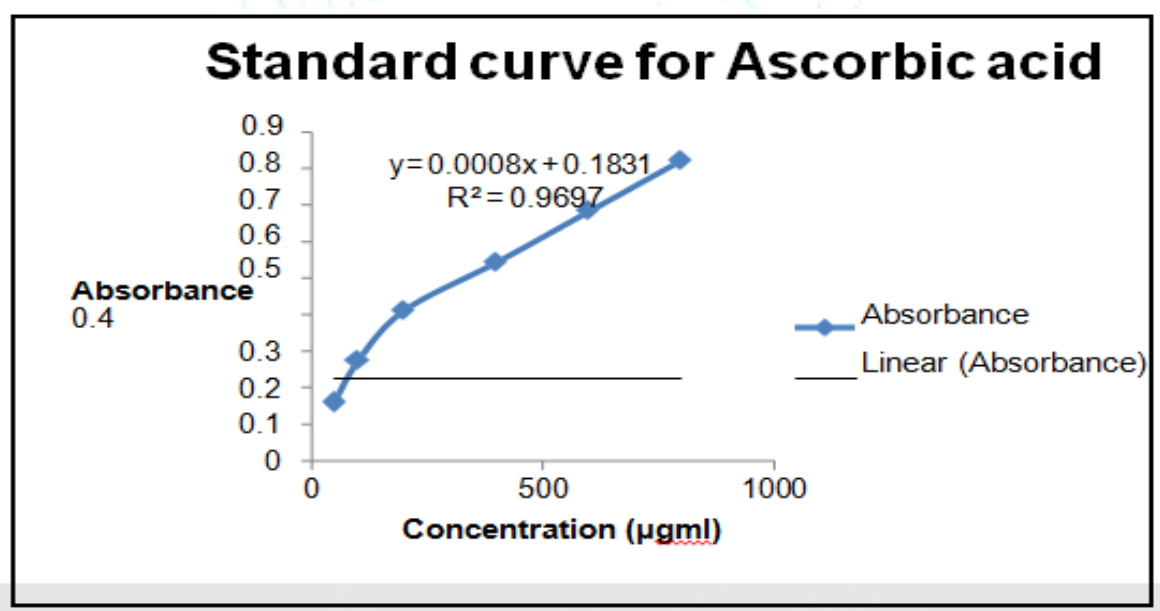

\section{DPPH radical scavenging activity}

The DPPH free radical scavenging activity was assessed by using in vitro method. The radical scavenging activity was expressed in terms of \% scavenging.

Table 2: Values of absorbance and percentage scavenging of both methanolic and aqueous extract with increase in concentration of extracts of Kigelia pinnata.

\begin{tabular}{|c|c|c|c|c|c|c|}
\hline \multirow{2}{*}{$\begin{array}{c}\text { Concentration } \\
(\boldsymbol{\mu g} / \mathbf{m l})\end{array}$} & \multicolumn{3}{|c|}{ Absorbance } & \multicolumn{3}{c|}{ \% Scavenging } \\
\cline { 2 - 7 } & $\begin{array}{c}\text { KPME } \\
\text { (Methanol) }\end{array}$ & $\begin{array}{c}\text { KPAE } \\
\text { (Aqueous) }\end{array}$ & $\begin{array}{c}\text { Standard } \\
\text { Ascorbic acid }\end{array}$ & KPME & KPAE & $\begin{array}{c}\text { Standard. } \\
\text { Ascorbic acid }\end{array}$ \\
\hline Control & $1.2631 \pm 0.070$ & $1.2631 \pm 0.070$ & - & - & - & - \\
\hline 50 & $0.764 \pm 0.009^{*}$ & $0.852 \pm 0.002^{*}$ & - & $39.30 \pm 2.77^{*}$ & $32.54 \pm 2.34^{*}$ & - \\
\hline 100 & $0.494 \pm 0.003^{*}$ & $0.526 \pm 0.005^{*}$ & $0.412 \pm 0.008$ & $60.72 \pm 2.13^{*}$ & $58.35 \pm 2.82^{*}$ & $67.30 \pm 2.43$ \\
\hline
\end{tabular}

Values are expressed as mean $\pm \mathrm{SEM}, * \mathrm{p}<0.05$ denotes significance with respect to the control group using ANOVA followed by student t-Test.

The DPPH free radical scavenging activity exhibited by both methanolic and aqueous extracts of Kigelia pinnata. The percentage scavenging activity ( $\%$ inhibition) was increased with increased in concentration of extracts. Methanolic extract of Kigelia pinnata $(100 \mu \mathrm{g} / \mathrm{ml})$ showed better scavenging activity as compared to aqueous extracts.

\section{Hydrogen peroxide scavenging activity}

The Hydrogen peroxide scavenging activity was assessed by using in vitro method. The radical scavenging activity was expressed in terms of \% inhibition. 
Table 3: Values of absorbance and percentage inhibition of both methanolic and aqueous extract with increase in concentration of extracts of Kigelia pinnata

\begin{tabular}{|c|c|c|c|c|c|c|}
\hline $\begin{array}{c}\text { Concentration } \\
(\mu \mathrm{g} / \mathrm{ml})\end{array}$ & \multicolumn{3}{|c|}{ Absorbance } & \multicolumn{3}{c|}{ \% Inhibition } \\
\cline { 2 - 7 } & $\begin{array}{c}\text { KPME } \\
(\text { Methanol) }\end{array}$ & KPAE (Aqueous) & $\begin{array}{c}\text { Ascorbic acid } \\
(\mathbf{s t d})\end{array}$ & KPME & $\begin{array}{c}\text { KPAE } \\
\text { Ascorbic } \\
\text { acid (std) }\end{array}$ \\
\hline Control & 0.015 & 0.015 & - & - & - & - \\
\hline 50 & $0.018 \pm 0.0075^{*}$ & $0.017 \pm 0.0016^{*}$ & - & $22.6 \pm 0.35^{*}$ & $13.2 \pm 0.24^{*}$ & - \\
\hline 100 & $0.019 \pm 0.0021^{*}$ & $0.018 \pm 0.0018^{*}$ & $0.020 \pm 0.23$ & $26.6 \pm 0.56^{*}$ & $22.6 \pm 0.46^{*}$ & $33 \pm 0.29$ \\
\hline
\end{tabular}

Values are expressed as mean $\pm \mathrm{SEM},{ }^{*} \mathrm{p}<0.05$ denotes significance with respect to the control group using ANOVA followed by student t-Test.

The Hydrogen peroxide scavenging activity exhibited by both methanolic and aqueous extracts of Kigelia pinnata. The percentage scavenging activity ( $\%$ inhibition) was increased with increased in concentration of extracts. Methanolic extract of Kigelia pinnata $(100 \mu \mathrm{g} / \mathrm{ml})$ showed better scavenging activity as compared to aqueous extracts.

\section{Wound Healing Activity:}

Incision wound healing model:

Better healing pattern and tensile strength was observed for the treated group on 10 day and was found to be significant than control group as shown in Table 5.4.

Table 4: Evaluation of KPME on incision wound model in rats.

\begin{tabular}{|c|c|c|c|}
\hline S.N. & Group & $\begin{array}{c}\text { Breaking Strength } \\
\text { (gm) (mean } \pm \text { SEM) }\end{array}$ & $\begin{array}{c}\text { Tensile Strength } \\
\text { (gm/mm } \mathbf{~}_{\mathbf{~ ( m e a n ~} \pm \text { SEM) }}\end{array}$ \\
\hline 1 & Control & $554 \pm 7.031$ & $2.91 \pm 0.016$ \\
\hline 2 & Standard & $740 \pm 9.032$ & $3.52 \pm 0.023$ \\
\hline 3 & KPME $2 \%$ & $710 \pm 8.022^{*}$ & $3.38 \pm 0.054^{*}$ \\
\hline 4 & KPME 4\% & $724 \pm 8.055^{*}$ & $3.44 \pm 0.045^{*}$ \\
\hline
\end{tabular}

Results were compared with control by ANOVA and p value was calculated by student t-test $\mathrm{p}^{*}<0.01, \mathrm{n}=6$

The tensile strength of the $4 \% \mathrm{w} / \mathrm{w}$ extract treated group and the Standard ointment treated group were comparable to each other. The $4 \% \mathrm{w} / \mathrm{w}$ extract ointment treated group showed significant increase in tensile strength compared to the control group (554)gm. The tensile strength of $4 \% \mathrm{w} / \mathrm{w}$ treated group was (3.44) gm/ $\mathrm{mm}^{2}$. Thus both concentrations of the extract as well as the standard drug showed a significant increase in tensile strength in the 9th day 32 .

The result shows that aerial parts Kigelia pinnata possesses a definite prohealing action.

\section{Excision wound healing model}

Topical application of the methanolic extracts of Kigelia pinnta showed a significant wound healing activity as evident by the reduction in the number of days required for falling of escher and the wound contraction as compared with that of standard. The results showed that the plant Kigelia pinnta possessed effective wound healing activity as compared to control group, there by justifying its use in the indigenous system of medicine.

Table 5: Wound healing effects of aerial parts of Kigelia pinnata (excision method)

\begin{tabular}{|c|c|c|c|c|}
\hline \multirow{2}{*}{ Post wound Week } & \multicolumn{4}{|c|}{ \% wound contraction } \\
\cline { 2 - 5 } & Control & Standard & KPME 2\% & KMME 4\% \\
\hline 0 & 0 & 0 & 0 & $42.77 \pm 1.34^{*}$ \\
\hline 1 & $19.03 \pm 0.32$ & $55.45 \pm 1.04$ & $86.47 \pm 1.34^{*}$ & $91.51 \pm 0.54^{*}$ \\
\hline 2 & $55.56 \pm 0.29$ & $92.32 \pm 0.38$ & $94.24 \pm 0.67^{*}$ & $95.39 \pm 0.39^{*}$ \\
\hline 3 & $72.72 \pm 0.53$ & $96 \pm 0.45$ & - & - \\
\hline 4 & $95.19 \pm 1.23$ & - & 24 & 22 \\
\hline
\end{tabular}

Values are expressed as mean \pm SEM $(\mathrm{N}=6),{ }^{*} \mathrm{p}<0.001$ denotes significance with respect to the control group using ANOVA followed by student $\mathrm{t}$-Test. 

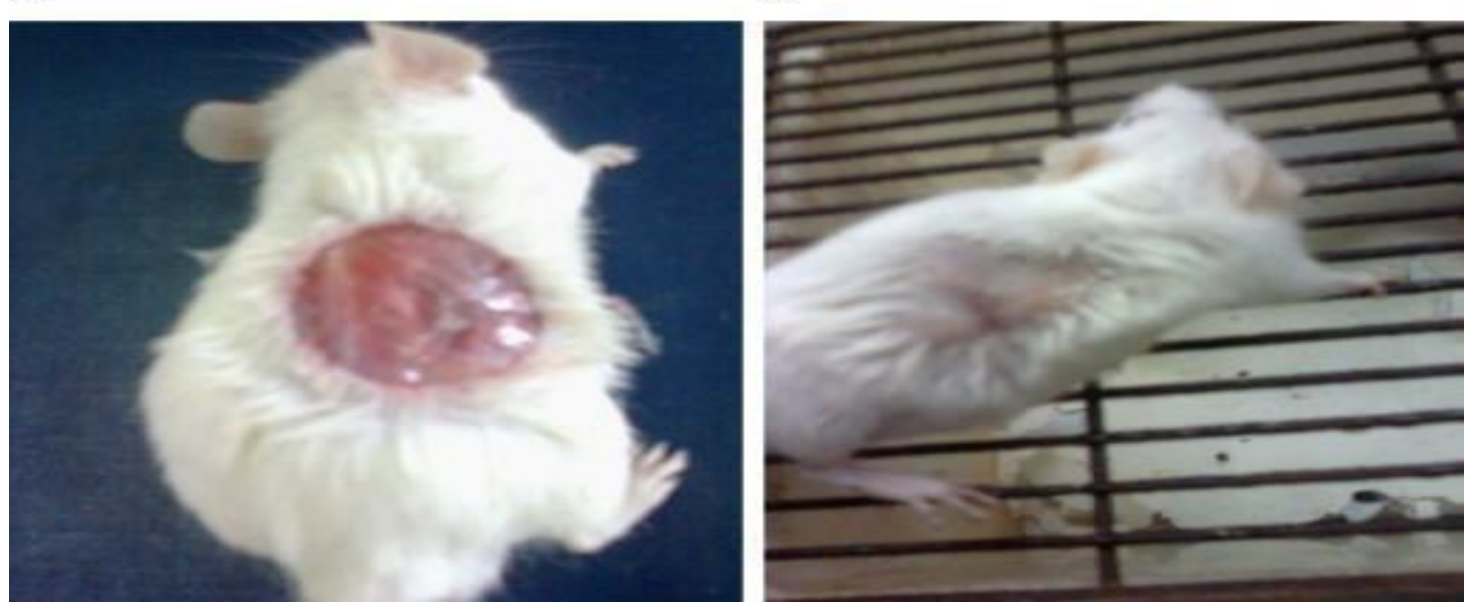

Figure 2: Showing wound area and the same part after healing

Changes in wound area were calculated giving an indication of the rate of wound contraction. The areas of the wounds were measured by tracing the wounds on to a graph paper on the day of wounding and subsequently on 7 th, $14^{\text {th }}$ th, 21 and $28^{\text {th }}$ day post wounding. The number of days required for falling of the scar without any residual raw wound, gave the period of epithelization. Topical administration of KPME accelerated the process of wound healing 33 . It was also observed that epithelization period of standard group and treated group was less in comparison with that of simple ointment base treated group.

\section{Anti-Microbial Activity}

Anti-bacterial activity

The result in Table 5 depicted the MIC values of the methanolic extract of aerial part of Kigelia pinnata against various tested bacterial pathogens.

Table 6: Determination of MIC of methanolic extract of aerial part of Kigelia pinnata against various bacterial strains:

\begin{tabular}{|c|c|c|c|c|c|c|c|c|c|}
\hline \multirow[t]{2}{*}{ S.No } & \multirow[t]{2}{*}{$\begin{array}{c}\text { Name of } \\
\text { microorganism }\end{array}$} & \multicolumn{8}{|c|}{$\begin{array}{l}\text { Dilution of methanolic aerial part extract }(\mu \mathrm{g} / \mathrm{mL}) \text { in } \\
\text { nutrient agar media }\end{array}$} \\
\hline & & $\mathbf{0}$ & 5 & 10 & 25 & 50 & 100 & 200 & 400 \\
\hline 1 & E. coli $\mathrm{BH} 07 / 12$ & + & + & + & + & + & - & - & - \\
\hline 2 & E. coli 306 & + & + & + & + & \pm & - & - & - \\
\hline 3 & E. coli $18 / 9$ & + & + & + & + & \pm & \pm & - & - \\
\hline 4 & V.cholerae 765 & + & + & + & + & Ic & - & - & - \\
\hline 5 & V. cholerae 556 & + & + & + & + & Ic & \pm & - & - \\
\hline 6 & Shigelia boylii & + & + & + & + & + & + & + & + \\
\hline 7 & Sh.dysenterae & + & + & + & + & \pm & \pm & \pm & - \\
\hline 8 & $\begin{array}{c}\text { Salmonella aureus } \\
\text { ML } 267\end{array}$ & + & + & + & + & + & + & + & + \\
\hline 9 & $\begin{array}{l}\text { Salmonella typhi } \\
\text { NCTC7447 }\end{array}$ & + & + & + & + & + & + & \pm & - \\
\hline 10 & $\begin{array}{l}\text { Bacillus substitis } \\
\text { MTC6441i }\end{array}$ & + & + & + & + & + & + & + & + \\
\hline
\end{tabular}

$\mathbf{0 =}$ control, \pm Inhibited Growth, + Growth, - Absence of Growth Ic= Isolated colonies

The analysis on the table 5 shows the antibacterial potentiality of the aerial part of the plant. The methanolic extract was shown to inhibit strains of E.coli within $50 \mu \mathrm{g} / \mathrm{ml}-400 \mu \mathrm{g} / \mathrm{ml}$ and strains of V.cholerae were inhibited at $100 \mu \mathrm{g} / \mathrm{ml}-400 \mu \mathrm{g} / \mathrm{ml}$. The strains of Shigelia boylii,
Salmonella aureus, Baccilus subtitis were found to be completely resistant 


\section{Determination of zone of inhibition:}

Table 7: Determination of zone of inhibition in $\mathbf{m m}$ produced by extract of Kigelia pinnata and its comparison with ciprofloxacin

\begin{tabular}{|c|c|c|c|c|c|}
\hline \multirow{2}{*}{ S.No. } & Name of bacteria & \multicolumn{2}{|c|}{$\begin{array}{c}\text { Extract }(\mu \mathrm{g} / \mathrm{ml}) \\
\text { Test }(\mathbf{m m})\end{array}$} & \multicolumn{2}{c|}{$\begin{array}{c}\text { Ciprofloxacin }(\boldsymbol{\mu g} / \mathbf{m l} \\
\text { standard) }(\mathbf{m m})\end{array}$} \\
\cline { 3 - 6 } & & $\mathbf{2 0 0}$ & $\mathbf{4 0 0}$ & $\mathbf{2 0 0}$ & $\mathbf{4 0 0}$ \\
\hline 1 & E. coli BH07/12 & 15 & 17 & 27 & 32 \\
\hline 2 & E. coli 306 & 11 & 13 & 27 & 35 \\
\hline 3 & E. coli 18/9 & 17 & 18 & 25 & 31 \\
\hline 4 & V.cholerae 765 & 12 & 14 & 29 & 33 \\
\hline 5 & V. cholerae 556 & 13 & 14 & 25 & 32 \\
\hline
\end{tabular}

The disc diffusion $(200 \mu \mathrm{g} / \mathrm{ml}$. and $400 \mu \mathrm{g} / \mathrm{ml})$ method was used to determine the zone of inhibition in comparison to ciprofloxacin as a standard against V.cholerae756, V.cholerae 556, E.coli18/9, E.coli-306, E.coli-BH07/12, were found to show good inhibitory results at $200 \mu \mathrm{g} / \mathrm{ml}, 400 \mu \mathrm{g} / \mathrm{ml}$ in (MIC) method. Further confirmatory tests using the disc diffusion method was performed on these bacteria which showed positive results in comparison with that of standard drug (ciprofloxacin). Result suggests that the methanolic extract of Kigelia pinnata exhibited significant antibacterial activity against all these bacteria.

\section{CONCLUSION}

The phytochemical investigation of the extract showed the presence of active compounds such as alkaloids, glycosides tannins, carbohydrates, saponins etc. The leaves of Kigelia pinnnata are rich in calcium, phosphorous and nitrogen, the elements like potassium, manganese, iron, zinc, copper, boron, sodium etc, are present in minor constitutes in the plant as shown in previous research. With the presence of such variety of minerals the plant can be used to overcome deficiencies.

The antioxidant activities of the extracts were mainly due to the presence of phenolic compounds such as flavonoids, tannis and phenolic diterpenes. Hence, the constituents of the extracts, such as tannins and flavonoids, plays a major role in the wound healing by preventing and protecting oxidative damage from free radicals. In antioxidant activities both DPPH and Hydrogen peroxide scavenging activity methods of $100 \mu \mathrm{g} / \mathrm{ml}$ extracts shows better \% inhibition as compared to control and $50 \mu \mathrm{g} / \mathrm{m}$ extracts. In DPPH Scavenging activity \% inhibition of $100 \mu \mathrm{g} / \mathrm{ml}$ methanolic extracts was $60.72 \%$ and in Hydrogen peroxide scavenging activity it was found to be $26 \%$.

The presence of moderate to high antimicrobial activity against the certain strains of wound dwelling bacteria and fungi correlate with its folklore use as wound healing agent. In incision wound healing model the tensile strength of the $4 \%$ extract treated group and the Neosporin ointment treated group were comparable to each other. The $2 \%$ extract ointment treated group showed lesser $3.38 \mathrm{gm} / \mathrm{mm}^{2}$ but significant increase in tensile strength compared to the control group $2.91 \mathrm{gm} / \mathrm{mm}^{2}$. The tensile strength of $4 \%$ treated group was $3.44 \mathrm{gm} / \mathrm{mm}^{2}$. Thus both concentrations of the extract as well as the standard drug showed a significant increase in tensile strength on the $9^{\text {th }}$ day .In excision models the animals treated with the 4\% w/w KPME ointment were shown to healed completely as compared to $2 \% \mathrm{w} / \mathrm{w}$ which was also at the complete healing stage as compared to control treated and the standard drug (Neosporin) treated group. The epithelization period of standard group and treated group was less in comparison with that of simple ointment base treated group which was 22 in the $4 \% \mathrm{w} / \mathrm{w}$ group and 24 in the $2 \% \mathrm{w} / \mathrm{w}$ group. The wound closure time was also less as well as the percentage of wound contraction was much more with the $4 \% \mathrm{w} / \mathrm{w}$ extract was similar to that of Neosporin treated group. $2 \% \mathrm{w} / \mathrm{w}$ treated group of animals showed significant wound contraction.

\section{REFERENCES}

1. Atolani O, Oladoye S, Oluyori A, Olatunji G, New Constituents of Kigelia pinnata leaves. Singapore Journal of Science and Research. 2012; 2(2):47-53.

2. Atolani O, Stephen O, Akpan E, Charles B, Olatunji G, Chemical Composition and Anitoxidant Potentials of Kigelia pinnata Root oil and Extracts. EXCLI Journal 2011; 10:264-723.

3. Bhattacharya S, Kumar A and Ghosal S., Antioxidant activity of Bacopa monnieri in rat frontal cortex, striatum and hippocampus, Phytotherapy Research. 2000; 14(3):174-179.

4. Bharti N, Singh S, Fehmida N, Isolation and In Vitro antiamobic activity of irridoids isolated from Kigelia pinnata. ARKIVOC 2006; 10(10):69-79.

5. Bole S, Dhritiv V, Chowdhary P, Rahul J and Vishank G, Free radical scavenging and anti-diabetic activity of Kigelia pinnata, World Journal of Pharmacy and Pharmaceutical Science, 2014; 3(4): 1249-1262.

6. Chaby G, Senet P, Vaneau M, Guillaume J, Meaume S, Teot L, Debure C, Dompmartin A, Bachelet H and Richard J, Dressing for acute and chronic wounds, Archives of Dermatology, 2007; 143(10): 1297-1304.

7. Cichewicz, R.H., Thorpe, P.A., The antimicrobial properties of chilli peppers (Capsicum species) and their uses in Mayan medicine, Journal of Ethnopharmacology, 1996; 52:61-70.

8. Deans S, Nobel R, Hiltunen R, Wuryani W and Penzen L, Antimicrobial and antioxidant properties of Syzygium aromaticum. Journal of Flavor and Fragrance, 1995; 10(5):323328.

9. Dorothy AN, Houghton PJ, Meroterpenoids and naphthoquinones from Kigelia pinnata. Phytochemistry, 1993; 32:1015-1018.

10. Douglas M, Alan L, and Miller N, Nutritional Support for wound Healing, Journal of Alternative Medicine, 2003; 8(4):359-377. 
11. Eckburg P, Lepp P and Relman D, Archea and their potential role in human disease, Advance Space Research, 2003; 2(2):45-53.

12. Fátima, A., Modolo, L.V., Sanches, A.C., Porto, R.R., Wound healing agents: the role of natural and non-natural products in drug development, Mini Review of Medicinal Chemestry, 2008; 9:879-88.

13. Gabriel OA, Olubunmi A, Comprehensive scientific demystification of Kigelia africina: A review. African Journal of Pure and Applied Chemistry, 2009; 3(9)158-64.

14. Govindachari TR, Patankar SJ, Vishvanathan N., Isolation and structure of two new dihydroisocoumarins from Kigelia pinnata. Phytochemistry, 1971; 10(7):1603-1606.

15. Shah S.K., Jhade D., Evaluation of antifertility potential ofPiper betle(Petiole) on female wistarrats"rising approaches of herbal contraception, Biochemistry and Biophysics Reports 2011; 8(5):97-102.

16. Hemamalini $\mathrm{K}$, Vasireddy $\mathrm{U}$, Bhargav A,Studies on phytochemical profile and analgesic activity of methanolic leaf extract of Kigelia africana (Lam) Benth and Sophora interrupta Bedd. International Journal of Pharmaceutical Sciences 2012; 4(2):1856-1870.

17. Ipek S, Esra A, Lutfun N, and Satyajit M., Wound healing and antioxidant properties: do they coexist in plants, Journal of Free Radicals and Anitoxidants, 2013; 2(2):213-220.

18. Jackson SJ, Houghton PJ, Retsas S, Photiou A, , In vitro cytotoxicity of norviburtinal and isopinnatal from Kigelia pinnata against cancer cell lines. Planta Medica, 2012; 66(8):758-761.

19. Rawat $\mathrm{M}$, Parmar $\mathrm{N}$ and Kumar T., Evaluation of Antiinflammatory potential of Kigelia pinnata leaf extract in wistar rat, Asian Journal of Pharmaceutical and Clinical Research, 2012; 5(1):96-97.

20. Keong L, Halim S., In vitro models in biocompatibility assessment for biomedical grade chitosan derivatives in wound management, International Journal of Molecular Sciences, 2009; 10:1300-1313.

21. Kumar D, Kumar S, Singh J, Narender R, Vashishta B, Singh N, Free radical Scavenging and analgesic Activities of cucumis sativus fruit extract, Journal of Young Pharmacist, 2010;2(4):365-368.

22. Kumar R, Kumar T, Kamboj V and Chander H., Pharmacological evaluation of ethanolic extract of Kigelia pinnata fruit against ethylene glycol induced urolithiasis in rats, Asian Journal of Plant Science and Research, 2012; 2(1):65-72.

23. Kumar S, Kumar V, Prakash 0,. Antidiabetic and hypolipidemic activities of Kigelia pinnata flower extract in streptozocin induced diabetic rats, Asian Pacific Journal of Tropical Biomedicine, 2012; 2(7):543-546.

24. Mathieu P, Rodero, Kiarash K, Skin wound healing modulation by macrophages. International Journal of Clinical Experimental Pathology, 2010; 3(7):643-645.

25. Mazumder R, Chaudhari S, and Mazumder A, Antimicrobial potentiality of a phenothiazine group of antipsychotic drugprochlorperazine. Indian Journal of Experimental Biology, 2002; 40(1):828-830.

26. Meena AK, Bansal P, Kumar S., Plants-herbal wealth as a potential source of ayurvedic drugs. Asian Journal of Traditional Medicine, 2009; 4(4), 152-153.

27. Momekova D, Momekov G, Pencheva I, Konstantikov S, Antineoplastic activity of a methanolic extract from Kigelia pinnata DC stem bark. Journal of Cancer Therpeutics and Research, 2012; 5:1-5.

28. Mukherjee PK, Sahu M, Suresh B., Recent trends of herbal medicines, Indian Herbal Medicines. The Eastern Pharmacist, 1998; 22:21-23.

29. Patil S, Naikwade N, Chougule D, Kigelia africina: Ethnomedicinal Uses and Pharmacological Studies. International Journal of Noval Research in Engineering and Pharmaceutical Sciences, 2014; 1(1):9-13.

30. Picerno P, Autore G, Marzocco S, Meloni M, Sanogo R, Aquino R. Anti- inflammatory Activity of Verminoside from Kigelia africana and Evaluation of Cutaneous Irritation in Cell Cultures and Reconstituted Human Epidermis. Journal of Natural Product, 2005; 68(11):1610-1614.

31. Rai D, Sharma U, Singh A, Kumar M and Agrahari P, Wond healing activity of Kigelia pinnata bark extract. Asian Journal of Pharmaceutical and Clinical Research, 2010; 3(4):74-75.

32. Tyagi C.K., Pal M., Shah S.K., Butea monosperma Bark Extract on Albino Wistar Rats, Ijppr.Human, 2018; 12(4):416-428.

33. Rawat $\mathrm{M}$, Parmar $\mathrm{N}$ and Kumar $\mathrm{T}$, Evaluation of Analgesic potential of Kigelia pinnata leaf extract in wistar rat. International Research Journals of Pharmacy, 2011; 2(10):8789. 